УДК $159.98: 316.77$

DOI https://doi.org/10.32782/humanitas/2021.6.14

\title{
Оксана ШЕВУУК
}

кандидат педагогічних наук, доцент, дочент кафедри соиіальної педагогіки та соиіальної роботи, Уманський державний педагогічний університет імені Павла Тичини, вул. Садова, 28, м. Умань, Черкаська область, Україна, 20308

ORCID: 0000-0002-1127-9807

Бібліографічний опис статті: Шевчук, О. (2021). Тренінг як засіб формування комунікативних здібностей майбутніх соціальних працівників. Bвічливість. Humanitas, 6, 99-104, doi: https://doi.org/10.32782/humanitas/2021.6.14

\section{ТРЕНІНГ ЯК ЗАСІБ ФОРМУВАННЯ КОМУНІКАТИВНИХ ЗДІБНОСТЕЙ МАЙБУТНІХ СОЦІАЛЬНИХ ПРАЦІВНИКІВ}

\begin{abstract}
У статті на основі теоретичного дослідження наукової проблеми, вивчення сучасної практики обтрунтовано використання тренінгових методів навчання у прочесі формування комунікативних здібностей майбутніх соиіальних працівників. Для дослідження проблеми було використано такі методи: теоретико-методичнии аналіз літературних джерел; включене та опосередковане спостереження; ретроспективний аналіз власного досвіду автора. Виявлено, щчо прочес формування комунікативних здібностей майбутніх сочіальних працівників повинен бути цілеспрямованим, систематичним та включати дієві методи та форми роботи. Одним із ефективних навчальних методів є тренінг. Встановлено, щуо тренінг сприяє розвитку у майбутніх соиіальних працівників відповідних комунікативних умінь, навичок та форм поведінки, які є важливою складовою його професійної підготовки. Адже саме за допомогою тренінгу у майбутнього сочіального працівника формується комплекс відповідних комунікативних умінь, навичок та форм поведінки, які є важливою складовою частиною його професійної підготовки. Ефективне формування комунікативних здібностей майбутніх сочіальних працівників можслве за умови використання таких тренінгових методів: методи групової дискусії; ділових, творчих, імітаційних ігор; «мозкового штурму»; методу кейсів; використання вербальних і невербальних технік та інші. Обтрунтовано, щзо зміст тренінгових методів навчання має бути спрямований на вироблення навичок у майбутніх соціальних працівників вступати у взаємодію з об'єктами соціальної діяльності, тактовно і цілеспрямовано вести з ними бесіду, ураховувати інтереси й потреби клієнта, розуміти мотиви вчинків і поведінки клієнтів, знаходити до них індивідуальний підхід, прогнозувати їхній розвиток, результати роботи. Особливо актуально застосувати тренінгові технології як засіб для створення комунікативних ситуацій, наближених до умов реального спілкування в майбутній професії.
\end{abstract}

Ключові слова: тренінг, тренінгові технологї, соціальний працівник, комунікативні здібності.

\section{Oksana SHEVCHUK}

Candidate of Pedagogical Sciences, Associate Professor, Associate Professor at the Department of Social Pedagogy and Social Work, Pavlo Tychyna Uman State Pedagogical University, 28 Sadova str., Uman, Cherkasy region, Ukraine, 20308

ORCID: 0000-0002-1127-9807

To cite this article: Shevchuk, O. (2021). Trening yak zasib formuvannya komunikativnih zdibnostej majbutnih socialnih pracivnikiv [Training as a means of forming the communicative abilities of future social workers]. Vvichlivist. Humanitas, 6, 99-104, doi: https://doi.org/10.32782/humanitas/2021.6.14

\section{TRAINING AS A MEANS OF FORMING THE COMMUNICATIVE ABILITIES OF FUTURE SOCIAL WORKERS}

In the article on the basis of theoretical research of scientific problem, study of modern practice the use of training methods of training in the process of formation of communicative abilities of future social workers is substantiated. The following methods were used to study the problem: theoretical and methodological analysis of literature sources; included and indirect observation; retrospective analysis of the author's own experience. It is revealed that the process of formation of communicative abilities of future social workers should be purposeful, systematic and include effective methods and forms of work. One of the effective teaching methods is training. It is established that the training promotes the development of future social workers of appropriate communication skills, abilities and behaviors, which are 
an important component of his training. After all, it is with the help of training that the future social worker forms a set of relevant communication skills, abilities and forms of behavior, which are an important component of his professional training. Effective formation of communicative abilities of future social workers is possible under the condition of using the following training methods: methods of group discussion; business, creative, simulation games; "Brainstorming"; case method; use of verbal and nonverbal techniques and others. It is substantiated that the content of training methods should be aimed at developing skills of future social workers to interact with objects of social activity, tactfully and purposefully talk to them, take into account the interests and needs of the client, understand the motives and actions of clients. their individual approach, to predict their development, results of work. It is especially important to use training technologies as a means to create communicative situations close to the conditions of real communication in the future profession.

Key words: training, training technologies, social worker, communication skills.

Актуальність проблеми. У формуванні комунікативних здібностей система тренінгів спрямована на вирішення таких завдань: закріплення знань про комунікаційні процеси; корекція, формування і розвиток установок, необхідних для успішної комунікативної діяльності; розвиток здатності адекватного пізнання себе та інших людей; корекція і розвиток міжособистісних відносин. Завдяки цьому відбувається переосмислення своїх можливостей та свого комунікативного потенціалу в розвитку фахових здібностей та їх презентації.

Саме за допомогою тренінгових технологій формуються і розвиваються комунікативні уміння, які є необхідними для майбутнього соціального працівника: уміння встановлювати контакт 3 клієнтом; прогнозувати можливі шляхи розвитку комунікативної ситуації, в рамках якої розгортається спілкування; ставити запитання; усвідомлювати і знімати внутрішні бар'єри в спілкуванні з клієнтами; психологічно вірно і залежно від ситуації вступити в спілкування; слухати співрозмовника за допомогою техніки активного слухання; прогнозувати реакції партнерів на власні акти комунікативних дій; спровокувати «бажану реакцію» партнера зі спілкування; орієнтуватися в ситуації клієнта, ведення діалогу; вирівнювати емоційне напруження в бесіді; стимулювати клієнта до прояснення його позиції, пропозицій тощо; максимально використовувати соціально-психологічні характеристики комунікативної ситуації для реалізації своєї стратегічної лінії; аргументувати свою точку зору; сприйняти і зрозуміти те, що співрозмовник не в змозі був висловити; підтримувати спілкування, стимулювати активність клієнта; точно визначити «крапку» в завершенні спілкування; донести клієнту інформацію, що його почули і зрозуміли; налаштовуватися на емоційний тон партнерів зі спілкування, заволодіти й утримати ініціативу в спілкуванні; формувати i «керувати» емоційним настроєм клієнта, створювати сприятливий соціально-психологічний клімат в спілкуванні; конструктивними способами виходити 3 конфліктних ситуацій та їх попередження та уміння приймати і передавати невербальну інформацію.

Аналіз останніх досліджень і публікацій. Дослідженню проблеми формування комунікативної компетентності та комунікативних здібностей студентів у процесі вивчення навчальних дисциплін присвячені праці О. Борзенко, Н. Гончаренко-Закревської, О. КравченкоДзонзи, О. Корніяки, І. Леонтьєвої та ін. Формування комунікативної та соціально-комунікативної компетентності майбутніх фахівців соціальної сфери розглядають у своїх дослідженнях I. Бєлецька, А. Стьопкін та ін. У даних наукових розвідках зосереджується увага на інтерактивних та тренінгових методах, вправах, які допомагають у формуванні комунікативних здібностей студентів.

Мета статті - обгрунтувати ефективність використання тренінгових методів навчання у процесі формування комунікативних здібностей майбутніх соціальних працівників.

Виклад основного матеріалу. Поняття «тренінг» у педагогіці розглядається як здобуття та засвоєння знань, формування і розвиток умінь, навичок, важливих якостей, ціннісних оріснтацій, компетентностей тощо. Це створює підгрунтя вважати тренінг технологією навчання (оскільки тренінг відповідає всім основним ознакам технології й охоплює у своїй структурі велику кількість окремих форм і методів).

У науковій та методичній літературі поняття тренінгу є багатозначним. Загалом тренінг трактується як форма спеціально-організованого спілкування, психологічний вплив якого грунтується на активних методах групової роботи. Тренінг є одночасно спілкуванням, цікавим процесом пізнання себе та інших, ефективною 
формою опанування знань, інструментом для формування вмінь та навичок, формою розширення досвіду (Манохіна, 2012).

У педагогічному словнику наукова дефініція «тренінг» розглядається як форма інтерактивного навчання, метою якої є розвиток міжособистісної та професійної поведінки (Коджаспирова, Коджаспиров, 2005: 520).

Поняття «тренінг» А. Панфілова тлумачить «як багатофункціональний метод цілеспрямованих змін психологічних феноменів людини, групи або організації 3 метою гармонізації професійного та особистісного буття людини» (Панфилова, 2006: 24).

У своїх дослідженнях Л. Новікова розглядає тренінг як «спеціально організований комплекс методів навчальної діяльності, завдань і вправ, спрямованих на формування, удосконалення і розширення досвіду» (Новікова, 2008: 16).

Свій підхід, відмінний від попередніх визначень, що стосується поняття «тренінг», дає О. Горбушіна і розглядає його як «яскраве, емоційне насичене заняття, спрямоване на зміну, гармонізацію стилю спілкування особистості, набуття бажаних навичок і розв'язання протиріч, які виникають у взаємодії з іншими людьми» (Горбушина, 2008: 9).

Розглянувши основні визначення, можемо зробити висновки, що у загальному розумінні тренінг розглядають як планомірно здійснювану програму різноманітних вправ, головним призначенням яких $\epsilon$ підвищення зацікавленості особистості у процесі засвоєння тих чи інших практичних умінь та навичок щодо вирішення різного роду завдань, пошук шляхів виходу зі складних ситуацій, подолання певних життєво важливих проблем тощо.

Розмаїття тлумачення поняття «тренінг» переконує нас у тому, що це $є$ не тільки універсальний метод розвитку особистості, але й найбільш ефективна модель роботи 3 групою клієнтів, оскільки у ньому теоретично і практично задіяна вся психологічна сфера особистості (інтелектуальна, емоційна, вольова, поведінкова тощо).

Аналіз наукової літератури дає нам підстави відокремити такі характерні особливості тренінгу:

1. Інтерактивність. У тренінгах акцентується увага на інтерактивному режимі, комунікації, постійній залученості групи у діалог.
Методи тренінгового навчання дозволяють більш ефективно обрати техніки подачі інформації відповідно до індивідуальних особливостей сприймання учасників. На тренінговому занятті учасники мають «говорити», «писати», «малювати», «грати», «відчувати на дотик», «переживати».

2. Атмосфера занять. Неформальна атмосфера проведення тренінгу, почуття розкутості та свободи в спілкуванні між учасниками групи, клімат психологічної безпеки, яка дозволяє кожному учаснику легко відкрито ділитися своїми думками, почуттями, проблемами.

3. Груповий процес. Група є відображенням суспільства у мініатюрі. Вона сприяє можливості кожному учаснику ідентифікувати себе 3 іншими, набувати нового досвіду. Водночас у групі найбільш ефективно забезпечується зворотній зв'язок та підтримка від інших.

4. Залученість. Через те, що заняття проводяться в максимально активному режимі, в учасника тренінгу просто немає вибору, доводиться засвоювати необхідну інформацію. Цьому сприяє сама атмосфера, в яку його занурюють.

5. Короткостроковість. Тренінгове заняття може тривати від 1 години до 1 робочого дня: це оптимальний термін, впродовж якого людина може 3 користю для себе витримати постійну «інформаційну атаку» та високі навантаження.

6. Ефективність. Тренінг побудований (повністю чи частково) на моделюванні ситуацій професійної діяльності учасників тренінгу та спрямований на формування умінь і навичок, необхідних у практичній роботі, формує практичні навички до виконання індивідуальних завдань і публічної презентації результатів своєї роботи, навчає ефективно працювати в команді (Галімов, 2009: 42).

Разом із тим вважаємо за доцільне звернути увагу на специфічні риси тренінгу, які виокремив А. Грецов. Він стверджує, що різноманітність тренінгів велика, проте для них характерні деякі загальні риси:

1. Дотримання низки принципів групової роботи: активність учасників; партнерське спілкування, що допускає визнання цінності особистості кожного з учасників; дослідницька позиція учасників у процесі групової роботи; надання учасникам можливість об'єктивного погляду на свою поведінку очами інших людей, 
засобом чого виступає зворотній зв'язок.

2. Акцент на взаєминах учасників групи. Система стосунків, що складається між учасниками групи під час роботи, називається груповою динамікою.

3. Наявність більш-менш постійної групи. Пропуски зустрічей не вітаються, а обговорювати події, що відбуваються в групі, за ії межами забороняється, оскільки це призводить до втрати тієї емоційної «енергії», яка повинна витрачатися в процесі роботи.

4. Просторова організація спрямована на те, щоб забезпечити найкращі можливості для інтенсивного спілкування учасників і звести до мінімуму зовнішні відволікаючі чинники.

5. Спрямованість на психологічну допомогу учасникам групи. Результат тренінгу не зводиться до формування в учасників системи знань і умінь, велике значення має суб' єктивне поліпшення психічного стану i отримання імпульсу подальшого саморозвитку. Тому разом із об'єктивними критеріями результативності тренінгів розглядається і суб' єктивні.

6. Атмосфера розкутості й свободи спілкування. Спілкування в умовах тренінгу інтенсивніше, емоційніше, більш відкрите і щире, ніж у звичайних міжособистісних контактах. На початкових етапах роботи 3 групою основним завданням тренера $\epsilon$ створення відповідної атмосфери, моделювання психологічного безпечних умов для такого спілкування (Федорчук, 2014: 28).

Сенс упровадження тренінгових технологій, на думку американського психолога М. Лакіна, $\epsilon$ спільним для різних навчальних груп і полягає у сприянні процесу самопізнання, самореалізації людини, уможливленні виявлення конструктивних змін особистості. Наприклад, доведено, що тренінги:

1) полегшують виявлення емоцій та почуттів;

2) створюють почуття приналежності до колективу;

3) спонукають до саморозкриття;

4) знайомлять із новими зразками поведінки;

5) дають можливість проаналізувати особистісні риси окремих членів групи;

6) сприяють розподілу відповідальності між тренером та іншими учасниками (Агапова, 2008).

Окрім того, тренінгові технології створюють атмосферу невимушеного обговорення особистісних проблем; пом'якшують побоювання помилитися, виглядати некомпетентним, закомплексованим тощо; дають змогу ознайомитися із загальними методичними прийомами групової роботи; розвивають компетентність у спілкуванні, наприклад, уміння встановити контакт зі співрозмовником, сприймати його емоційний стан, вміння сприймати й передавати інформацію, бути учасником або керівником дискусії; сприяють корекції, формуванню та розвитку установок, необхідних для успішного спілкування, розв'язання конфліктних ситуацій, розвитку емоційної стійкості до складних життєвих ситуацій; розвивають уміння і потреби у пізнанні інших людей, гуманістичне ставлення до них.

Ефективне формування комунікативних здібностей майбутніх соціальних працівників можливе за умови використання спеціальних прийомів і тренінгових методів. Найбільш успішними можна назвати: методи групової дискусії; ділових, творчих, імітаційних ігор; «мозкового штурму»; методу кейсів; використання вербальних і невербальних технік та інші.

Так, у ході групової дискусії учасники навчаються управлінню груповим процесом обговорення проблеми, що дозволяє прояснити позиції, весь спектр думок і установок учасників тренінгу, а так само можливість їх зміни в процесі безпосереднього спілкування.

3 одного боку, учасники тренінгу навчаються різноманітним способам знаходження ефективних рішень, що можна застосовувати в різних ситуаціях. 3 іншого, групова дискусія створює ефективне середовище, у якому формуються комунікативні здібності, рефлексія, розвивається креативність тощо.

Використання ігрових методів $є$ високоефективним, тому що в рольовій грі акцент робиться на міжособистісну взаємодію. До ігрових методів належать дидактичні ігри, тобто спеціально створені ситуації, які моделюють різні ситуації спілкування і які учасники тренінгу повинні самостійно вирішувати, обираючи собі ту або іншу роль. Ігри сприяють створенню близьких стосунків між учасниками групи, знімають напруженість, тривогу, страх перед оточуючими, підвищують самооцінку, дозволяють перевірити себе в різних ситуаціях спілкування, знімаючи небезпеку соціально значимих наслідків (Лалак, 2017; Фесенко, Хомула, 2009). 
На тренінгу також можуть бути використані методи обговорення і вирішення кейсів, які розглядаються як проблемна ситуація, що вимагає відповіді та знаходження рішення. Основне завдання кейса - навчитися аналізувати інформацію, виявляти основні проблеми і шляхи вирішення, формувати програму дій (Вдовенко, 2017).

Використання таких методів тренінгу сприяє розвитку умінь майбутніх фахівців усвідомлювати проблемну професійну ситуацію, аналізувати дану ситуацію та свою поведінку в ній, виробляти уміння професійної поведінки, яка $\epsilon$ оптимальною у даній професійній ситуації, та найефективніше ії вирішує.

Комплексні інтерактивні та комунікативні уміння корелюють із техніками спілкування, опрацювання яких відбувається в процесі проведення тренінгу. До таких технік відносяться: техніка встановлення контакту; техніка активного слухання; техніка інформування; техніка переконання; техніка аргументування; техніка зниження емоційної напруги.

Також у тренінг можуть бути включені вправи, метою яких є формування м'язової свободи в процесі спілкування, розвиток навичок довільної уваги, спостережливості, розвиток навичок невербального спілкування, формування уміння керувати увагою партнерів по спілкуванню та ін.

Найчастіше до тренінгової програми, яка спрямована на формування комунікативних здібностей, входять: ознайомлення зі стадіями та видами спілкування, встановлення контакту, орієнтація на розуміння проблеми, техніки активного слухання, невербальне спілкування (передача інформації, передача емоцій, вико- ристання жестів), пошук спільного рішення, використання аргументів, прийняття рішення, вихід $з$ контакту.

Висновки i перспективи подальших досліджень. Отже, процес формування комунікативних здібностей майбутніх соціальних працівників повинен бути цілеспрямованим, систематичним та включати дієві методи та форми роботи. Одним із ефективних навчальних методів є тренінг. Адже саме за допомогою тренінгу у майбутнього соціального працівника формується комплекс відповідних комунікативних умінь, навичок та форм поведінки, які є важливою складовою частиною його професійної підготовки.

Зміст тренінгових методів навчання має бути спрямований на вироблення навичок у майбутніх соціальних працівників вступати у взаємодію з об' єктами соціальної діяльності, тактовно і цілеспрямовано вести 3 ними бесіду, ураховувати інтереси й потреби клієнта, розуміти мотиви вчинків і поведінки клієнтів, знаходити до них індивідуальний підхід, прогнозувати їхній розвиток, результати роботи. Особливо актуально застосувати тренінгові технології як засіб для створення комунікативних ситуацій, наближених до умов реального спілкування в майбутній професії.

Здійснене нами дослідження, однак, не вичерпує всієї проблематики щодо формування комунікативних здібностей майбутніх соціальних працівників засобам тренінгу. Подальшого вивчення потребують: формування комунікативних якостей майбутніх соціальних працівників, використання навчальних тренінгів у процесі професійної підготовки.

\section{ЛITEPATУРА:}

1. Вдовенко О. Використання інноваційних технологій у професійно-технічних навчальних закладах в процесі підготовки майбутнього кваліфікованого робітника. Проблеми підготовки сучасного вчителя. 2017. № 15. C. $148-155$.

2. Галімов А.В. Дослідження можливостей соціально-психологічного тренінгу щодо формування комунікативних та емпатійних якостей майбутніх фахівців соціальної сфери. Збірник наукових праць Хмельницького інституту соиіальних технологій Університету «Україна». 2009. № 1. С. $42-47$.

3. Горбушина О.П. Психологический тренинг. Секреты проведения. Санкт-Петербург : Питер, 2008. 176 с.

4. Коджаспирова Г.М., Коджаспиров А.Ю. Словарь по педагогике. Москва : ИКЦ «МарТ», 2005. 659 с.

5. Лалак Н.В. Інтерактивна модель навчання студентів: проблеми та перспективи. Науковий вісник Ужгородського наиіонального університету: Серія «Педагогіка. Соціальна робота». Збірник наукових праиь. 2017. № 1(27). Вип. 20. С. 69-70.

6. Манохіна I. Тренінг як засіб формування готовності майбутнього соціального педагога до роботи з дітьмисиротами та дітьми, позбавленими батьківського піклування. Проблеми сучасної педагогічної освіти. Педагогіка і психологія. 2012. Вип. 37(2). С. 16-22. 
7. Новікова Л.М. Тренінг як засіб активізації навчання у вищій школі : навч.-метод. посіб. Павлоград : Максимус-К, 2008. $110 \mathrm{c}$.

8. Панфилова А.П. Тренинг педагогического общения : учеб пособие для студ. высш. учеб. заведений. Москва : Издательский центр «Академия», 2006. 336 с.

9. Технологии образования взрослых. Пособие для тех, кто работает в системе образования взрослых / под общей редакцией О.В. Агаповой, С.Г. Вершловского, Н.А. Тоскиной. Санкт-Петербург : КАРО, 2008. 176 с.

10. Федорчук В.М. Тренінг особистісного зростання : навч. посіб. Київ : «Центр учбової літератури», 2014. $250 \mathrm{c}$.

11. Фесенко В., Хомула А. Інтерактивні методики - найкращий шлях до досягнення вершин професійної майстерності. Вища школа. 2009. № 12. С. 39-44.

\section{REFERENCES:}

1. Vdovenko, O. (2017). Vykorystannia innovatsiinykh tekhnolohii u profesiino-tekhnichnykh navchalnykh zakladakh $\mathrm{v}$ protsesi pidhotovky maibutnoho kvalifikovanoho robitnyka [The use of innovative technologies in vocational schools in the process of training future skilled workers]. Problemy pidgotovky suchasnogo vchytelya-Problems of modern teacher training, 15, 148-155 [in Ukrainian].

2. Galimov, A.V. (2009). Doslidzhennya mozhlivostej socialno-psihologichnogo treningu shodo formuvannya komunikativnih ta empatijnih yakostej majbutnih fahivciv socialnoyi sferi [Research of possibilities of social and psychological training on formation of communicative and empathic qualities of future specialists in the social sphere]. Zbirnik naukovih prac Hmelnickogo institutu socialnih tehnologij Universitetu «Ukrayina» - Collection of scientific works of the Khmelnytsky Institute of Social Technologies of the University "Ukraine», 1, $42-47$ [in Ukrainian].

3. Gorbushina, O.P. (2008). Psihologicheskij trening. Sekrety provedeniya [Psychological training. Secrets of conducting]. SPb. : Piter [in Russian].

4. Kodzhaspirova, G.M., \& Kodzhaspirov, A.Yu. (2005). Slovar po pedagogike [Dictionary of Pedagogy]. M. : IKC «MarT» [in Russian].

5. Lalak, N.V. (2017). Interaktyvna model navchannia studentiv: problemy ta perspektyvy [Interactive model of student learning: problems and prospects]. Naukovyj visnyk Uzhgorodskogo nacionalnogo universytetu: Seriya «Pedagogika. Socialna robota». Zbirnyk naukovyx pracz - Scientific Bulletin of Uzhhorod National University: Series «Pedagogy. Social work». Collection of scientific works, 1 (27), issue 20, 69-70 [in Ukrainian].

6. Manohina, I. (2012). Trening yak zasib formuvannya gotovnosti majbutnogo socialnogo pedagoga do roboti z ditmi-sirotami ta ditmi, pozbavlenimi batkivskogo pikluvannya [Training as a means of forming the readiness of the future social educator to work with orphans and children deprived of parental care]. Problemi suchasnoyi pedagogichnoyi osviti. Pedagogika i psihologiya - Problems of modern pedagogical education. Pedagogy and psychology, Issue 37 (2), 16-22 [in Ukrainian].

7. Novikova, L.M. (2008). Trening yak zasib aktivizaciyi navchannya u vishij shkoli [Training as a means of intensifying learning in higher education]. Pavlograd : Maksimus-K [in Ukrainian].

8. Panfilova, A.P. (2006). Trening pedagogicheskogo obsheniya [Training of pedagogical communication]. M. : Izdatelskij centr «Akademiya» [in Russian].

9. Agapova, O.V. (Eds.). (2008). Tehnologii obrazovaniya vzroslyh. Posobie dlya teh, kto rabotaet $v$ sisteme obrazovaniya vzroslyh [Adult education technologies. A guide for those working in the adult education system]. $\mathrm{SPb}$. : KARO [in Russian].

10. Fedorchuk, V.M. (2014). Trening osobistisnogo zrostannya [Personal growth training]. K. : «Centr uchbovoyi literaturi» [in Ukrainian].

11. Fesenko, V., \& Homula, A. (2009). Interaktyvni metodyky - naikrashchyi shliakh do dosiahnennia vershyn profesiinoi maisternosti [Interactive techniques are the best way to reach the top of professionalism]. Vyshha shkolaHigh school, 12, 39-44 [in Ukrainian]. 